\title{
Sub-lethal Effects of Diazinon on Hematological Indices and Blood Biochemical Parameters in Indian Carp, Cirrhinus mrigala (Hamilton)
}

\author{
Muhammad Jamal Haider ${ }^{1}$ and Abdul Rauf ${ }^{2 *}$ \\ ${ }^{I}$ Department of Zoology; Federal Urdu University for Arts, Science \& Technology; Gulshan-e-Iqbal campus; \\ Karachi - Pakistan. ${ }^{2}$ Department of Zoology; Govt. Superior Degree Science College; Shah Faisal Colony; Karachi \\ - Pakistan
}

\begin{abstract}
Indian carp (Cirrhinus mrigala) exposed to two sub-lethal concentrations $(0.815 \mathrm{mg} / \mathrm{L}$ and $1.63 \mathrm{mg} / \mathrm{L})$ of diazinon for 30 days showed a significant decrease in erythrocyte count, hemoglobin concentration, hematocrit, mean corpuscular volume, mean corpuscular hemoglobin, plasma levels of total protein, albumin, globulin, activity of enzyme acetylcholinesterase and a significant increase in plasma glucose levels when compared with controlled fish $(P<0.05)$. Compared to the controlled fish, leukocyte count decreased significantly in fish exposed to both sub-lethal concentrations and the plasma activities of enzyme asparate aminotransferase and alanine aminotransferase increased significantly after 20 and 30 days in fish exposed to $0.815 \mathrm{mg} / \mathrm{L}$ of diazinon, while the activities of these enzymes in fish exposed to 1.63 $\mathrm{mg} / \mathrm{L}$ of diazinon increased significantly at all sampling periods $(P<0.05)$. On the other hand, the plasma activity of the enzyme lactate dehydrogenase decreased significantly in both diazinon treated fish groups after 10 days of exposure $(P<0.05)$ and returned to the normal value after 20 and 30 days of exposure. In conclusion, long-term exposure to diazinon at sub-lethal concentrations induces severe physiological alterations in $\mathrm{C}$. mrigala that may potentially disrupt their survival in their natural habitat.
\end{abstract}

Key words: Diazinon, toxicity, hematology, biochemistry, Indian carp (Cirrhinus mrigala)

\section{INTRODUCTION}

Pesticides contribute to a dramatic increase in crop yields; on the other hand the contamination of water bodies through spray drift and leaching from the soil may induce undesirable ecological and hazardous health effects on a variety of non-target organisms including fish. The pollution of surface water caused by pesticides used in agriculture and their effects on non-target organisms are problems of global importance (Hill 1985). Organophosphate pesticides are extensively being used in agriculture and account for approximately $50 \%$ of the global pesticide use (John 2007). Diazinon is an organophosphate pesticide, it is widely used in agriculture to protect many crops from a wide range of Hymenopterans and Hemipteran insects (Abass et al. 2011). After application in agriculture, diazinon easily washes into surface water and ultimately reaches to ponds, rivers and lakes. Previous studies have evidenced rapid degradation of diazinon but its continual input makes its presence persistent in aquatic bodies for a long time and causes stress to aquatic organisms ( $\mathrm{Li}$ et al. 2002). Like other organophosphate pesticides, diazinon produces its toxic effects by inhibiting a series of enzymes, including acetylcholinesterase that can severely affect growth, survival, reproduction and feeding behaviors of fish (Chons et al. 2005). Depending

*Author for correspondence: abdulrauf75@hotmail.com 
upon the differences in absorption, detoxification and acetylcholinesterase inhibition, the $96 \mathrm{~h} \mathrm{LC}_{50}$ values of diazinon vary in different fish species. The $96 \mathrm{~h} \mathrm{LC}_{50}$ value of diazinon for zebra fish (Brachydanio rerio) has been reported as $8 \mathrm{mg} / \mathrm{L}$ and for Guppy fish (Poecillia reticulate) as 0.8 $\mathrm{mg} / \mathrm{L}$ (Keizer et al. 1991). Hematological and biochemical parameters can be detected rapidly and found to be sensitive to sub-lethal concentration of different toxic agents. Therefore, the variations of these parameters can be used for prediction and diagnosis of pesticide toxicity (Burkepile et al. 2000). Hematological and biochemical changes induced by sub-lethal concentrations of different organophosphate pesticides have previously been investigated in several fish species. Such as, dichlorvos in Clarias batrachus (Benarji and Rajendranath 1990), formothion in Heteropneustes fossilis (Singh and Srivastava 1994), malathion in Clarias gariepinus (Ahmad 2012), diazinon in Silurus glanis (Koprucu et al. 2006) and Cyprinus carpio (Ahmad 2011). Diazinon is commonly used in agriculture and previous studies have reported contamination of fresh water reservoirs in Pakistan with diazinon and its derivatives (Mastoi et al. 2008; Iram et al. 2009). However, there is a paucity of data regarding the effects of diazinon on local fish fauna. Indian carp (Cirrhinus mrigala) is an important freshwater fish with considerable economic importance in Pakistan. Therefore, the present study was conducted to investigate the effects of sub-lethal concentrations of diazinon on hematological and biochemical parameters of the C. mrigala. Ultimately, this study would supplement current knowledge on pesticide toxicity and management of fresh water reservoirs regarding diazinon input from agricultural fields.

\section{MATERIALS AND METHODS}

A group of immature Indian carp, C. mrigala weighing $65.80 \pm 10.20 \mathrm{~g}$ and total length of 12.28 $\pm 2.41 \mathrm{~cm}$ were purchased from Jokhio fish farm ( $24^{\circ} 16^{\prime} 5^{\prime \prime}$ North, $67^{\circ} 35^{\prime} 55^{\prime \prime}$ East) Thatta, located Northeast of Karachi, Pakistan. Fish were transported in aerated plastic containers to the laboratory and kept in two $1000 \mathrm{~L}$ fiberglass tanks for two weeks to acclimatize to the laboratory conditions. The water in the tanks was aerated continuously, changed daily and its temperature was maintained at $22 \pm 2{ }^{\circ} \mathrm{C}$. During the period of acclimation, a commercial fish food was offered to fish twice a day, but the fish were deprived of food for $24 \mathrm{~h}$ prior to the experiment and throughout the acute toxicity test. Whereas, fish were fed once a day during sub-lethal toxicity test and feeding was stopped $24 \mathrm{~h}$ before blood sampling.

After two weeks of acclimation, a static acute toxicity test was carried out following the guidelines of OECD (1992). Basudin $60 \mathrm{EC}$, with active ingredient diazinon [0,0-diethyl-0-(2isopropyl-6-methyl-4-pyrimidyl)

phosphorothioate], purity $60 \%$ dissolved in $40 \%$ acetone was purchased from Syngenta Ltd. Pakistan and used to prepare test solutions of diazinon. Fish were exposed to six different concentrations $(5,10,15,20,25$, and $30 \mathrm{mg} / \mathrm{L})$ of diazinon to determine $1,24,48,72$ and $96 \mathrm{~h} \mathrm{LC}_{50}$ values for the test fish. Five aquaria were used for each concentration and each aquarium contained ten fish in $250 \mathrm{~L}$ dechlorinated tap water. Prior to the introduction of fish in the aquaria, diazinon was added and water was aerated for an hour for homogenous distribution of diazinon in the water. Two control sets containing the same number of fish and the same volume of water, but without diazinon were also run. The water quality parameters of experimental water used were: $\mathrm{pH}$ $7.5 \pm 0.3$, temperature $22 \pm 2{ }^{\circ} \mathrm{C}$, dissolved oxygen $6.9 \pm 0.5 \mathrm{mg} / \mathrm{L}$, total hardness $118.5 \pm 1.4 \mathrm{mg} / \mathrm{L}$ as $\mathrm{CaCO}_{3}$ and these were determined according to the procedures described in standard methods (APHA 1985). Fish status, behavior and water quality parameters were monitored throughout the test and water in the aquaria was changed daily. Fish were considered dead if their gill opercular movement ceased and they failed to respond to the stimulus provided by a glass rod. Fish mortalities were recorded after 1, 24, 48, 72 and $96 \mathrm{~h}$ of exposure; dead fish were immediately removed from the aquaria and Probit Analysis test was used to calculate LC $_{50}$ values (Finney 1971).

A sub-lethal toxicity test was performed at the end of $96 \mathrm{~h}$ acute toxicity test. Fish were exposed to two sub-lethal concentrations of diazinon i.e. $0.815 \mathrm{mg} / \mathrm{L}$ and $1.63 \mathrm{mg} / \mathrm{L}(10 \%$ and $20 \%$ of $96 \mathrm{~h}$ $\mathrm{LC}_{50}$ respectively) for 30 days. Sub-lethal toxicity test was performed in nine $250 \mathrm{~L}$ glass aquaria and each aquarium contained ten fish. Three control aquaria without diazinon and three aquaria were used for each sub-lethal concentration. The water quality parameters were maintained the same as were used for the acute toxicity test. Fresh test media were provided daily to minimize the 
accumulation of metabolic wastes and to ensure the presence of diazinon near to the nominal level. The behavioral changes of fish were recorded after every $12 \mathrm{~h}$, whereas hematological and biochemical examinations were carried out in 10, 20 and 30 days of exposure. After each exposure period, six fish from each exposure concentration and six control fish were caught randomly using a small dip net with minimum disturbance in the aquaria. Fish were wrapped and cleaned with a common filter paper. Blood was collected by cardiac puncture using $18 \mathrm{G}$ needle attached to a plastic syringe. Blood was transferred into heparanized glass vials (50 IU Sodium heparin/ $\mathrm{ml}$ of blood) and was immediately used for hematological examinations. The hematological parameters investigated were erythrocyte count (RBC), hemoglobin concentration $(\mathrm{Hb})$, hematocrit (Hct), mean corpuscular volume $(\mathrm{MCV})$, mean corpuscular hemoglobin $(\mathrm{MCH})$, mean corpuscular hemoglobin concentration (MCHC), leukocyte count (WBC) and these were determined according to the unified methods for hematological examination of fish (Svobodova et al. 1991). For biochemical analyses, blood was centrifuged at $400 \mathrm{rpm}$ for 15 minutes at $4{ }^{\circ} \mathrm{C}$. Plasma was separated and was used to determine plasma Glucose (GLU), Total proteins (TP), Albumins (ALB), Globulins (GLOB), activities of enzyme acetylcholinesterase (AChE), Asparate aminotransferase (AST), Alanine aminotransferase (ALT) and Lactate dehydrogenase (LDH). The biochemical analyses of plasma were carried out using UANTI B1000 Fully Automatic Biochemistry Analyzer (Aurora Biomed Inc. Canada).

Data for hematological and biochemical parameters were tested for normality (Kolmogorov-Smirnov test) and were analyzed by one way analysis of variance (ANOVA) to test significant differences among measured variables of the control and experimental fish groups. The results were presented as mean \pm SD. All statistical analyses were carried out using SPSS 17.0 computer software (SPSS Inc. Chicago, USA) and $\mathrm{P}<0.05$ was considered significant.

\section{RESULTS}

The mean $\mathrm{LC}_{50}$ values of diazinon recorded for Indian carp, $C$. mrigala at $1,24,48,72$ and $96 \mathrm{~h}$ are given in Table 1 . The data clearly indicated a significant decrease in $\mathrm{LC}_{50}$ values as exposure time to diazinon increased. $96 \mathrm{~h} \mathrm{LC}_{50}$ is the basic value in the acute toxicity test and it was found to be $8.15 \mathrm{mg} / \mathrm{L}$ of diazinon for C. mrigala. Fish mortalities were not recorded during sub-lethal toxicity experiment as the diazinon concentrations used were $10 \%$ and $20 \%$ of $96 \mathrm{~h} \mathrm{LC}_{50}$. However, fish exposed to diazinon showed some behavioral changes. These changes include, accelerated gill movement; loss of coordinated body movement; fish lying on their side or hanging vertically in the water; seizures and convulsions. Compared to the controlled group, the fish exposed to diazinon showed a significant decrease in RBCs, $\mathrm{Hb}, \mathrm{Hct}$, $\mathrm{MCV}$ and $\mathrm{MCH}$ after 10 days of exposure $(\mathrm{P}<0.05)$. These parameters also showed a substantial reduction during further exposure periods. The total WBC count of exposed fish showed a delayed decrease. The WBC count of controlled and exposed fish were not significantly different from each other after 10 days of exposure to diazinon, but after 20 days and 30 days of exposure, a significant decrease in WBC count of both exposed fish groups was observed when compared to controlled fish group. Whereas MCHC values of controlled and exposed fish groups were not significantly different from each other during all exposure periods (Table 2).

Table 1 - Mean lethal concentrations of diazinon to Indian carp, C. mrigala

\begin{tabular}{|c|c|}
\hline Duration of exposure (h) & $\mathrm{LC}_{50}(\mathrm{mg} / \mathrm{L})$ \\
\hline 1 & $17.32(15.91-18.32)$ \\
\hline 24 & $13.39(14.32-16.22)$ \\
\hline 48 & $12.64(11.32-13.44)$ \\
\hline 72 & $10.98(9.71-11.42)$ \\
\hline 96 & $8.15 \quad(9.14-7.33)$ \\
\hline
\end{tabular}

$\mathrm{LC}_{50}$ were calculated by the probit analysis test and the results are expressed as mean $\pm \mathrm{SD}$.

Results of plasma biochemical profile indicated a significant increase in plasma glucose levels $(\mathrm{P}<0.05)$ and a significant decrease in plasma levels of total protein, albumin, globulin and plasma activity of AChE in diazinon exposed fish at all sampling periods $(\mathrm{P}<0.05)$. The AST and ALT activities in plasma of fish exposed to 0.815 $\mathrm{mg} / \mathrm{L}$ were not significantly different from controlled group after 10 days exposure, but increased significantly after 20 days and 30 days exposure $(\mathrm{P}<0.05)$. On the other hand, the plasma activities of these enzymes increased significantly in fish exposed to $1.63 \mathrm{mg} / \mathrm{L}$ diazinon at all sampling intervals. Therefore, a significant dosedependent difference was observed in the activities of ALT and AST between $0.815 \mathrm{mg} / \mathrm{L}$ and 1.63 
$\mathrm{mg} / \mathrm{L}$ of diazinon treatments in exposed fish. Compared to the controlled fish group, LDH activity decreased significantly in both exposed fish groups only after 10 days of exposure and returned to the normal values after 20 and 30 days of exposure (Table 3 ).

Table 2 - Alterations in the hematological parameters of Indian carp, C. mrigala after 30 days exposure to $0.815 \mathrm{mg} / \mathrm{L}$ and $1.63 \mathrm{mg} / \mathrm{L}$ of diazinon.

\begin{tabular}{lcccc}
\hline Parameters & $\begin{array}{c}\text { Exposure time } \\
\text { (days) }\end{array}$ & Controlled group & \multicolumn{2}{c}{ Experimental groups } \\
\cline { 4 - 5 } RBC $\left(10^{6} / \mathrm{mm}^{3}\right)$ & 10 & $1.56 \pm 0.01^{\mathrm{a}}$ & $1.14 \pm 0.16^{\mathrm{b}}$ & $\mathbf{1 . 6 3 ~ m g / L}$ \\
& 20 & $1.55 \pm 0.12^{\mathrm{a}}$ & $1.04 \pm 0.02^{\mathrm{b}}$ & $0.99 \pm 0.06^{\mathrm{b}}$ \\
$\mathrm{Hb}(\mathrm{g} / \mathrm{dL})$ & 30 & $1.55 \pm 0.14^{\mathrm{a}}$ & $0.98 \pm 0.09^{\mathrm{b}}$ & $0.97 \pm 0.10^{\mathrm{b}}$ \\
& 10 & $5.18 \pm 0.16^{\mathrm{a}}$ & $4.10 \pm 0.03^{\mathrm{b}}$ & $4.03 \pm 0.18^{\mathrm{b}}$ \\
$\mathrm{Hct}(\%)$ & 20 & $5.15 \pm 0.21^{\mathrm{a}}$ & $4.01 \pm 0.13^{\mathrm{b}}$ & $3.92 \pm 0.21^{\mathrm{b}}$ \\
& 30 & $5.16 \pm 0.11^{\mathrm{a}}$ & $3.90 \pm 0.06^{\mathrm{b}}$ & $3.04 \pm 0.31^{\mathrm{c}}$ \\
$\mathrm{MCV}(\mathrm{fL})$ & 10 & $31.46 \pm 0.21^{\mathrm{a}}$ & $28.21 \pm 1.10^{\mathrm{b}}$ & $26.34 \pm 0.17^{\mathrm{b}}$ \\
& 20 & $30.32 \pm 0.42^{\mathrm{a}}$ & $27.30 \pm 1.02^{\mathrm{b}}$ & $24.86 \pm 0.42^{\mathrm{b}}$ \\
$\mathrm{MCH}(\mathrm{pg})$ & 30 & $30.14 \pm 0.30^{\mathrm{a}}$ & $25.14 \pm 0.98^{\mathrm{b}}$ & $23.02 \pm 0.63^{\mathrm{b}}$ \\
& 10 & $238.41 \pm 3.21^{\mathrm{a}}$ & $221.33 \pm 4.32^{\mathrm{b}}$ & $219.55 \pm 3.85^{\mathrm{b}}$ \\
$\mathrm{MCHC}(\%)$ & 20 & $237.39 \pm 2.14^{\mathrm{a}}$ & $215.48 \pm 5.41^{\mathrm{b}}$ & $212.71 \pm 4.45^{\mathrm{b}}$ \\
& 30 & $232.71 \pm 2.74^{\mathrm{a}}$ & $211.52 \pm 4.69^{\mathrm{b}}$ & $209.25 \pm 4.65^{\mathrm{b}}$ \\
$\mathrm{WBC}\left(10^{3} / \mathrm{mm}^{3}\right)$ & 10 & $35.24 \pm 1.21^{\mathrm{a}}$ & $32.64 \pm 1.48^{\mathrm{b}}$ & $31.13 \pm 1.91^{\mathrm{b}}$ \\
& 20 & $36.04 \pm 0.28^{\mathrm{a}}$ & $30.32 \pm 1.16^{\mathrm{b}}$ & $24.46 \pm 0.91^{\mathrm{b}}$ \\
& 30 & $35.84 \pm 0.41^{\mathrm{a}}$ & $29.18 \pm 1.96^{\mathrm{b}}$ & $24.26 \pm 0.31^{\mathrm{b}}$ \\
& 10 & $17.04 \pm 1.26^{\mathrm{a}}$ & $16.32 \pm 1.04^{\mathrm{a}}$ & $16.28 \pm 1.33^{\mathrm{a}}$ \\
& 20 & $17.06 \pm 1.16^{\mathrm{a}}$ & $16.16 \pm 1.21^{\mathrm{a}}$ & $15.36 \pm 0.45^{\mathrm{a}}$ \\
& 30 & $17.02 \pm 0.94^{\mathrm{a}}$ & $16.21 \pm 1.09^{\mathrm{a}}$ & $15.11 \pm 1.29^{\mathrm{a}}$ \\
& 10 & $35.08 \pm 0.28^{\mathrm{a}}$ & $34.32 \pm 0.98^{\mathrm{a}}$ & $32.35 \pm 1.15^{\mathrm{a}}$ \\
& 20 & $36.21 \pm 0.14^{\mathrm{a}}$ & $26.54 \pm 0.47^{\mathrm{b}}$ & $24.42 \pm 0.97^{\mathrm{b}}$ \\
& 30 & $35.39 \pm 0.45^{\mathrm{a}}$ & $27.42 \pm 1.32^{\mathrm{b}}$ & $24.56 \pm 0.68^{\mathrm{b}}$ \\
\hline
\end{tabular}

$\mathrm{RBC}=$ erythrocyte count; $\mathrm{Hb}=$ hemoglobin concentration; Hct=hematocrit; $\mathrm{MCV}=$ mean corpuscular volume; $\mathrm{MCH}=$ mean corpuscular hemoglobin; $\mathrm{MCHC}=$ mean corpuscular hemoglobin concentration; $\mathrm{WBC}=$ leukocyte count. Different superscript letters in rows indicate significant difference $(\mathrm{P}<0.05)$ in groups.

Table 3 - Alterations in the biochemical parameters of Indian carp, C. mrigala after 30 days exposure to $0.815 \mathrm{mg} / \mathrm{L}$ and $1.63 \mathrm{mg} / \mathrm{L}$ of diazinon.

\begin{tabular}{|c|c|c|c|c|}
\hline \multirow{2}{*}{ Parameters } & \multirow{2}{*}{$\begin{array}{l}\text { Exposure } \\
\text { time (days) }\end{array}$} & \multirow[t]{2}{*}{ Controlled group } & \multicolumn{2}{|c|}{ Experimental groups } \\
\hline & & & $0.815 \mathrm{mg} / \mathrm{L}$ & $1.63 \mathrm{mg} / \mathrm{L}$ \\
\hline \multirow[t]{3}{*}{ GLU (mg/dL) } & 10 & $120 \pm 4^{\mathrm{a}}$ & $130 \pm 4^{b}$ & $138 \pm 5^{\mathrm{b}}$ \\
\hline & 20 & $122 \pm 2^{\mathrm{a}}$ & $139 \pm 5^{b}$ & $140 \pm 4^{b}$ \\
\hline & 30 & $124 \pm 5^{\mathrm{a}}$ & $133 \pm 5^{\mathrm{b}}$ & $142 \pm 6^{\mathrm{b}}$ \\
\hline \multirow[t]{3}{*}{$\mathrm{TP}(\mathrm{g} / \mathrm{dL})$} & 10 & $5.32 \pm 0.04^{\mathrm{a}}$ & $3.44 \pm 0.17^{b}$ & $3.62 \pm 0.12^{\mathrm{b}}$ \\
\hline & 20 & $5.10 \pm 0.18^{\mathrm{a}}$ & $3.38 \pm 0.21^{\mathrm{b}}$ & $3.51 \pm 0.04^{b}$ \\
\hline & 30 & $5.12 \pm 0.23^{\mathrm{a}}$ & $3.41 \pm 0.14^{\mathrm{b}}$ & $3.24 \pm 0.21^{\mathrm{b}}$ \\
\hline \multirow[t]{3}{*}{$\operatorname{ALB}(g / d L)$} & 10 & $2.54 \pm 0.03^{\mathrm{a}}$ & $1.98 \pm 0.21^{\mathrm{b}}$ & $2.00 \pm 0.31^{\mathrm{b}}$ \\
\hline & 20 & $2.39 \pm 0.16^{\mathrm{a}}$ & $1.87 \pm 0.27^{\mathrm{b}}$ & $1.70 \pm 0.42^{b}$ \\
\hline & 30 & $2.43 \pm 0.22^{\mathrm{a}}$ & $1.94 \pm 0.06^{\mathrm{b}}$ & $1.72 \pm 0.18^{b}$ \\
\hline \multirow[t]{3}{*}{ GLOB (g/dL) } & 10 & $2.64 \pm 0.18^{\mathrm{a}}$ & $1.98 \pm 0.16^{\mathrm{b}}$ & $1.97 \pm 0.24^{\mathrm{b}}$ \\
\hline & 20 & $2.48 \pm 0.05^{\mathrm{a}}$ & $1.85 \pm 0.22^{\mathrm{b}}$ & $1.87 \pm 0.03^{\mathrm{b}}$ \\
\hline & 30 & $2.35 \pm 0.09^{\mathrm{a}}$ & $1.96 \pm 0.29^{\mathrm{b}}$ & $1.91 \pm 0.18^{\mathrm{b}}$ \\
\hline \multirow[t]{3}{*}{$\operatorname{AChE}(\mathrm{U} / \mathrm{L})$} & 10 & $7686 \pm 105^{\mathrm{a}}$ & $3942 \pm 186^{\mathrm{b}}$ & $2896 \pm 162^{b}$ \\
\hline & 20 & $7513 \pm 121^{\mathrm{a}}$ & $3684 \pm 139^{\mathrm{b}}$ & $2532 \pm 159^{b}$ \\
\hline & 30 & $7662 \pm 118^{\mathrm{a}}$ & $3274 \pm 144^{\mathrm{b}}$ & $2148 \pm 172^{b}$ \\
\hline \multirow[t]{3}{*}{$\operatorname{AST}(\mathrm{IU} / \mathrm{L})$} & 10 & $433 \pm 22^{\mathrm{a}}$ & $452 \pm 26^{\mathrm{a}}$ & $568 \pm 48^{b}$ \\
\hline & 20 & $451 \pm 18^{\mathrm{a}}$ & $657 \pm 32^{b}$ & $591 \pm 56^{\mathrm{c}}$ \\
\hline & 30 & $448 \pm 28^{a}$ & $646 \pm 29^{\mathrm{b}}$ & $794 \pm 69^{c}$ \\
\hline \multirow[t]{3}{*}{$\operatorname{ALT}(\mathrm{IU} / \mathrm{L})$} & 10 & $15.2 \pm 3.2^{\mathrm{a}}$ & $17.8 \pm 3.9^{\mathrm{a}}$ & $20.5 \pm 6.9^{b}$ \\
\hline & 20 & $17.3 \pm 2.4^{\mathrm{a}}$ & $19.3 \pm 6.2^{\mathrm{b}}$ & $38.9 \pm 8.2^{\mathrm{c}}$ \\
\hline & 30 & $16.4 \pm 3.7^{\mathrm{a}}$ & $40.8 \pm 4.8^{\mathrm{b}}$ & $56.7 \pm 7.6^{\mathrm{c}}$ \\
\hline \multirow[t]{3}{*}{ LDH (IU/L) } & 10 & $197 \pm 14^{\mathrm{a}}$ & $166 \pm 18^{\mathrm{b}}$ & $160 \pm 22^{b}$ \\
\hline & 20 & $202 \pm 16^{\mathrm{a}}$ & $187 \pm 22^{\mathrm{a}}$ & $178 \pm 18^{\mathrm{a}}$ \\
\hline & 30 & $196 \pm 21^{\mathrm{a}}$ & $195 \pm 14^{\mathrm{a}}$ & $192 \pm 21^{\mathrm{a}}$ \\
\hline
\end{tabular}

GLU=Plasma glucose; TP=Total proteins; $\mathrm{ALB}=\mathrm{Albumins;} \mathrm{GLOB}=$ Globulins; $\mathrm{AChE}=$ activities of enzyme acetylcholinesterase; $\mathrm{AST}=\mathrm{Asparate}$ aminotransferase; ALT=Alanine aminotransferase; $\mathrm{LDH}=$ Lactate dehydrogenase $(\mathrm{LDH})$. Different superscript letters in rows indicate significant differences $(\mathrm{P}<0.05)$ in groups. 


\section{DISCUSSION}

In the present study, 1 and $96 \mathrm{~h} \mathrm{LC}_{50}$ values of diazinon for $C$. mrigala were found to be 17.32 $\mathrm{mg} / \mathrm{L}$ and $8.15 \mathrm{mg} / \mathrm{L}$ respectively. In view of this, diazinon can be considered moderately toxic substance for the fish. Diazinon toxicity for $C$. mrigala increased with increasing concentration and exposure time. Only $22 \%$ fish died when they were exposed to $5 \mathrm{mg} / \mathrm{L}$ of diazinon for $96 \mathrm{~h}$, whereas $100 \%$ fish died after $24 \mathrm{~h}$ when fish were exposed to $25 \mathrm{mg} / \mathrm{L}$ of diazinon. The acute toxicity values of diazinon vary in different fish species and range in tenths to several tens of $\mathrm{mg} / \mathrm{L}$ of diazinon. Keizer et al. (1991) reported 96 h LC 50 values of diazinon for zebra fish (Brachydanio rerio) as $8 \mathrm{mg} / \mathrm{L}$ and for guppy (Poecilia reticulate) as $0.8 \mathrm{mg} / \mathrm{L}$. Office of pesticide programme (2000) reported $96 \mathrm{~h} \mathrm{LC}_{50}$ values of diazinon for sheep head minnow (Cyprinodon variegates) as $1.47 \mathrm{mg} / \mathrm{L}$ and for fathead minnow (Pimephales minnow) as $7.80 \mathrm{mg} / \mathrm{L}$. Ahmed (2011) estimated $9.76 \mathrm{mg} / \mathrm{L}$ for common carp (Cyprinus carpio) and Soltani et al. (2012) reported $0.4 \mathrm{mg} / \mathrm{L}$ of diazinon as $96 \mathrm{~h} \mathrm{LC}_{50}$ values for male brood stock Rutilus frisii kutum. The difference in diazinon toxicity among different fish species can be attributed to the difference in their age, size, duration of exposure, susceptibility and tolerance regarding absorption, biotransformation and excretion of diazinon. The degree of diazinon sensitivity also varies even among the fish of the same family and genus (Ramesh and Saravanan 2008). In the present study, the $96 \mathrm{~h} \mathrm{LC}_{50}$ values of diazinon recorded for immature $C$. mrigala are slightly higher than reported for other fish species, indicating that $C$. mrigala are more resistant to diazinon and their mortality requires higher dosage and longer exposure time.

Compared to the controlled fish group, the hematological response of $C$. mrigala exposed to $0.815 \mathrm{mg} / \mathrm{L}$ and $1.63 \mathrm{mg} / \mathrm{L}$ of diazinon for 30 days was a significant decrease in $\mathrm{RBC}, \mathrm{Hb}, \mathrm{HCT}$, MCV, MCH and WBC count. The decrease in RBC, WBC counts and values of other hematological parameters in C. mrigala can be attributed to the failure or suppression of hematopoietic system of the fish, caused by longterm exposure to diazinon. These results are consistent with the findings of other studies investigating hematological response of different fish species exposed to other organophosphate pesticides. It regards, changes in hematological indices after exposure to malathion in Clarias gariepinus (Ahmad 2012), phosalone in Oreochromis mossambicus (Ali and Rani 2009) and trichlorfon in C. carpio (Al-Ghanim et al. 2008). Similar to the present findings, decreased RBC count, WBC count, hemoglobin and hematocrit levels have been reported in male brood stock, Rutilus frisii kutum (Soltani et al. 2012) and grass carp, Ctenopharyngodon idella (Pourgholam et al. 2006) after long-term exposure to sub-lethal concentrations of diazinon. Khoshbavar-Rostami et al. (2004) and Adedeji et al. (2009) also reported decreased Hb, RBC and WBC count and increased values of MCV and $\mathrm{MCH}$ after diazinon exposure in giant sturgeon (Huso huso) and African catfish, C. gariepinus respectively.

Compared to the controlled fish group, the biochemical response of $C$. mrigala exposed to $0.815 \mathrm{mg} / \mathrm{L}$ and $1.63 \mathrm{mg} / \mathrm{L}$ of diazinon for 30 days was a significant increase in the plasma glucose level, activities of AST and ALT; and a significant decrease in the plasma levels of TP, ALB, GLOB, activities of $\mathrm{AChE}$ and $\mathrm{LDH}$. Glucose is the primary source of energy and its increased plasma level is a secondary indicator of stress response in animals. In our results, the elevated level of glucose in diazinon exposed fish indicates diazinon induced stress in the test fish. Increased blood glucose levels have also been reported in $C$. carpio and in Oncorhynchus mykiss after longterm exposure to sub-lethal concentrations of diazinon (Ahmad 2011; Banaee et al. 2011). The reactive oxygen species produced during diazinon metabolism in fish liver, can lead to increase in the permeability of hepatocytes, kidney, gills, spleen and heart cells that results in leakage of AST, ALT and other enzymes into the plasma (Srivastava et al. 2004). In the present study, the increased activities of AST and ALT in the plasma of $C$. mrigala indicate that long-term exposure to diazinon caused tissue damage in fish. Increase in the plasma activities of AST and ALT has also been reported in O. mykiss and Channa punctatus, exposed to diazinon and monocrotophos respectively (Banaee et al. 2011; Agrahari et al. 2006). Albumin and globulin make up most of the total protein part of the body and their tests are used to monitor disorders of the immune system, renal and hepatic dysfunctions (Giron-Pirez et al. 2007). The decrease in total protein, albumin and globulin levels in diazinon exposed C. mrigala 
may be attributed to malnutrition and destruction of hepatocytes caused by diazinon toxicity. Other studies have also reported pesticide induced hepatic impairment and decreased levels of total protein, albumin, globulin in C. idella and $O$. mykiss exposed to diazinon (Pourgholam et al. 2006; Banaee et al. 2011) and C. carpio, exposed to cypermethrin (Dobšíková et al. 2006). Enzyme $\mathrm{AChE}$ is present in synaptic regions of neurons and mediates transmission of impulse by breaking acetylcholine into acetic acid and choline. Diazinon induced suppressed activity of AChE results in accumulation of acetylcholine at neural and neuromotor regions that causes hyper excitability and ultimately influences fish behavior (Cong et al. 2009). The decreased activity of AChE and altered behavioral response of $C$. mrigala in present study supports the findings of previous studies. It regards, decreased activity of AChE and behavioral changes in O. mykiss exposed to 0.1 and $0.2 \mathrm{mg} / \mathrm{L}$ of diazinon for 28 days (Banaee et al. 2011). A similar response has also been reported in green sturgeon, Huso huso and snake headed fish, Channa striata exposed to diazinon (Khoshbavar-Rostami et al. 2004; Cong et al. 2009). The plasma activity of LDH also helps to determine tissue damage in fish. In our study, LDH activity in both exposed fish groups decreased after 10 days of exposure to diazinon and returned to the normal level after 20 days and 30 days of exposure. Similar to our results, decreased LDH activity after exposure to other organophosphate pesticides has also been reported in O. mykiss (Banaee et al., 2011), C. punctatus (Agrahari et al. 2006) and C. gariepinus (Yekeen and Fawole 2011). However, in the present study, the recovery of LDH activity after 20 and 30 days of exposure indicates that diazinon concentrations used in the present study were not enough to cause persistent alterations in LDH activity of $C$. mrigala.

\section{CONCLUSION}

In conclusion, diazinon was moderately toxic to Indian carp, Cirrhinus mrigala, but sub-lethal exposure to diazinon for 30 days resulted on stress and induced significant hematological and biochemical changes. This study clearly indicates that the presence of diazinon in fresh water reservoirs, even in small concentration, could cause deleterious effects on fish physiology and may potentially disturb their survivability in the natural environment. Therefore, controlling measures should be taken to prevent the possible contamination of the aquatic environment by such toxic pesticides.

\section{REFERENCES}

Abass A, Kudi AC, Moodi AJ. Spontaneous reactivation and aging kinetics of acetylcholinesterase inhibited by dichlorvos and diazinon. J Toxicol Sci. 2011; 36: 237-241.

Adedeji OB, Adeyemo OK, Agbede SA. Effects of diazinon on blood parameters in the African catfish (Clarias gariepinus). Afr J Biotech. 2009; 8: 39403946.

Agrahari S, Gopal K, Pandey K. Biomarkers of monocrotophos in a freshwater fish Channa punctatus (Bloch). J Environ Biol. 2006; 27: 453-457.

Ahmad Z. Acute toxicity and haematological changes in common carp (Cyprinus carpio) caused by diazinon exposure. Afr J Biotech. 2011; 10: 1385213859.

Ahmad Z. Toxicity bioassay and effects of sub-lethal exposure of malathion on biochemical composition and hematological parameters of Clarias gariepinus. Afr J Biotech. 2012; 11: 8578-8585.

Al-Ghanim KA, Hmoud F, Al-Kahem A, Ali S, Fahad A, Ahmad Z, et al. Ethological response and haematological and biochemical profiles of carp (Cyprinus carpio) exposed to trichlorfon. J Food Agri Environ. 2008; 6: 473-479.

Ali JHA, Rani VJ. Effect of phosalone on haematological indices in the Tilapia, Oreochromis mossambicus. Turk J Vet Anim Sci. 2009; 33: 407411.

APHA (American Public Health Association). Standard methods for the examination of water and wastewater. $18^{\text {th }}$ ed. Washington DC: American Public Health Association Publications; 1994.

Banaee M, Sureda A, Mirvaghefi AR, Ahmadi K. Effects of diazinon on biochemical parameters of blood $\mathrm{n}$ rainbow trout (Oncorhynchus mykiss). Pest Biochem Physiol. 2011; 99: 1-6.

Benarji G, Rajendranath T. Hematological changes induced by an organophosphorus insecticide in a freshwater fish Clarias batrachus (L.). Trop Fresh Bio. 1990; 2: 197-202.

Burkepile DE, Moore MT, Holland MM. The susceptibility of five non-target organisms to aqueous diazinon exposure. Bull Environ Contam Toxicol. 2000; 64: 114-121.

Chons TS, Chung N, Kwak IS, Kim, JS, Koh SC, Lee SK, et al. Movement behavior of Medaka (Oryzias latipes) in response to sub-lethal treatments of diazinon and cholinesterase activity in semi-natural conditions. Environ Monit Assess. 2005; 101: 1-21. 
Cong NV, Phuong NT, Bayley M. Effects of repeated exposure of diazinon on cholinesterase activity and growth in snakehead fish (Channa striatus). Ecotoxicol Environ Saf. 2009; 72: 699-703.

Dobšíková R, Velíšek J, Wlasow T, Gomulka P, Svobodová Z, Novotný L. Effects of cypermethrin on some haematological, biochemical and histopathological parameters of common carp (Cyprinus carpio L.) Neuro Endocrinol Lett. 2006; 27: 101-105.

Finney DJ. Probit analysis. $3^{\text {rd }}$ ed. New York: Cambridge University Press; 1971.

Giron-Pirez MI, Santerre A, Gonzalez-Jaime F, CasasSolis J, Hernandez-Coronado M, Peregrina-Sandoval $\mathrm{J}$, et al. Immunotoxicity and hepatic function evaluation in Nile Tilapia (Oreochromis niloticus) exposed to diazinon. Fish Shellfish Immun. 2007; 23: 760-769.

Hill IR. Effects on non target organisms in terrestrial and aquatic environments. In: Lehey JP, editor. The Pyrethroid Insecticides. London: Taylor \& Francis; 1985. p. 165-181.

Iram S, Ahmad I, Ahad K, Muhammad A, Anjum S. Analysis of pesticides residues of Rawal and Simly lakes. Pak J Bot. 2009; 41(4); 1981-1987.

John PJ. Alteration of certain blood parameters of freshwater teleost Mystus vittatus after chronic exposure to Metasystox and Sevin. Fish Physiol Biochem. 2007; 33: 15-20.

Keizer J, DeAgostino G, Vittozzi I. The importance of biotransformation in the toxicity of xenobiotics to fish: Toxicity and bioaccumulation of diazinon in guppy (Poecilia reticulata) and zebra fish (Brachydanio rerio). Aquat Toxicol. 1991; 21: 239254.

Khoshbavar-Rostami H, Soltani M, Hassan HMD. Acute toxicity and some hematological and biochemical changes in giant sturgeon (Huso huso) exposed to diazinon. Bull Eur Asso Fish Pathol. 2004; 24: 92-99.

Koprucu SS, Koprucu K, Ural MS, Ispir U, Pala M. Acute toxicity of organophosphorous pesticide diazinon and its effects on behavior and some hematological parameters of fingerling European catfish (Silurus glanis). Pest Biochem Physiol. 2006; 86: 99-105.

Li PCH, Swanson HE, Gobas FAPC. Diazinon and its degradation products in agricultural water courses in British Columbia, Canada. Bull Environ Contam Toxicol. 2002; 69: 59-65.
Mastoi GM, Shah GS, Khuhawar MY. Assessment of water quality of Manchar Lake in Sindh (Pakistan). Environ Monit Assess. 2008; 141(1-3) :287-296

Office of Pesticide Programs. Annual report 2000. Washington DC: Pesticide ecotoxicity database, Environmental fate and effects division, United States Environmental Protection Agency; 2000.

OECD (Organization for Economic Co-operation and Development). Test Guideline 203, Fish acute toxicity test. Adopted guidelines June; 1992.

Pourgholam R, Soltani M, Hassan DM, Ghoroghi A, Nahavandi R, Pourgholam H. Determination of diazinon $\mathrm{LC}_{50}$ in Grass carp (Ctenopharyngodon idella) and the effect of sub-lethal concentration of toxin on some hematological and biochemical indices. Iranian J Fish Sci. 2006; 5: 67-82.

Ramesh M, Saravanan M. Hematological and biochemical responses in freshwater fish Cyprinus carpio exposed to Chloropyrifos. Int J Integ Bio. 2008; 3: 80-84.

Singh NN, Srivastava AK. Formothion induced hematological changes in the freshwater Indian cat fish, Heteropneustes fossilis. J Ecotox Environ Monit. 1994; 4: 137-140.

Soltani MNSM, Kamali A, Imanpoor MR, Sharifpour I, Khara H. Effects of organophosphate, diazinon on some haematological and biochemical changes in Rutilus frisii kutum (Kamensky, 1901) male brood stocks. Iranian J Fish Sci. 2012; 11: 105-117.

Srivastava AS, Oohara I, Suzuki T, Shenouda S, Singh SN, Chauhan DP, et al. Purification and properties of cytosolic alanine aminotransferase from the liver of two freshwater fish, Clarias batrachus and Labeo rohita. Comp Biochem Physiol B Biochem Mol Biol. 2004; 137(2): 197-207.

Svobodova Z, Pravda D, Palackova J. Unified methods of haematological examination of fish. $1^{\text {st }}$ ed. Vodnany: Research Institute of Fish Culture and Hydrobiology; 1991.

Yekeen TA, Fawole OO. Toxic effects of endosulfan on haematological and biochemical indices of Clarias gariepinus. Afr J Biotech. 2011; 10: 14090-14096.

Received: June 12, 2013; Accepted: January 30, 2014. 